\title{
New opportunities for future tourism after 25 years of political and socioeconomic transformation - foresight in Poland's tourism planning
}

Matylda Awedyk and Agnieszka Niezgoda

Matylda Awedyk is an Associate Professor at the Department of Tourism and Recreation, E.Piasecki University School of Physical Education, Poznań, Poland. Agnieszka Niezgoda is based at the Department of Tourism, Poznań University of Economics, Poznań, Poland.

Received 29 May 2015

Revised 31 July 2015

14 September 2015

17 September 2015

Accepted 22 September 2015

○ Matylda Awedyk and Agnieszka Niezgoda. Published in the Journal of Tourism Futures. This article is published under the Creative Commons Attribution (CC BY 4.0) licence. Anyone may reproduce, distribute, translate and create derivative works of this article (for both commercial and non-

commercial purposes), subject to full attribution to the original publication and authors. The full terms of this licence may be seen at: http://creativecommons.org/ licences/by/4.0/legalcode

\begin{abstract}
Purpose - The purpose of this paper is to present the changes in political and socioeconomic conditions after 25 years of transformation and how it provided to adopt new methodology in tourism planning. It shows the possibilities offered by the use of the foresight process in planning the development of tourism in Poland. Since one of the main foresight goals is to identify trends, the paper takes attempt to verify trends that occurred in Poland after 1989 and if they have now and will have in the near future influence on Polish tourism. Detailed objective is to characterize the systemic transformation and its impact on the tourism economy.

Design/methodology/approach - Paper is the review, which used literature, legislation and strategic documents query. It also includes comparative analysis.

Findings - The analysis of the political and economic changes that have taken place in Poland over the last 25 years shows that they were positive for the development of tourism base. The impact of globalization and global trends is now clearly noticeable also in Poland. Political and economic changes allow the use of foresight methodology in studies on the future of tourism while maintaining its main attributes: anticipation, participation, action, networking, vision.

Research limitations/implications - The analysis included the impact of political changes and social trends on the tourist economy. Proposals that show the positive aspects of these changes relate to tourism and present extensive opportunities to create scenarios, both at the national and regional levels.

Practical implications - The analysis forms the basis for the activities of tourism entities in Poland. It shows the characteristics for the future of the tourism market particularly the demand side.

Social implications - The analysis of changes in systemic and social trends enables anticipation of changes in tourism as a social phenomenon.

Originality/value - The paper presents the historical basis for the development of tourism in Poland after political changes in relation to the planning of tourism by using the methodology of foresight. It also presents these phenomena and social trends that have an impact on the development of tourism.
\end{abstract}

Keywords Foresight, Poland, Transformation, Future tourism, Political changes, Socioeconomic changes Paper type Research paper

\section{Introduction}

The political changes that occurred in Poland after 1989, crucially influenced the organization, structure and functioning of the state, society and economy. After 1989, economic and social solutions were introduced that would lead to the full compatibility between the real needs of the society in the field of tourism market and the functioning of the tourism economy. Obtaining conformity required time and the social acceptance of reforms. 
Foresight, particularly within the European Union, is a very comprehensive and current topic at the international and regional level (Popper et al., 2007; Georghiou et al., 2008; Da Costa et al., 2008; Loveridge, 2009; Hilbert et al., 2009; Öner, 2010; Jemala, 2010; Destatte, 2010; Coates, 2010; Colwell and Narayanan, 2010; Könnölä et al., 2011; Daffara, 2011; Meissner, 2012; van Asselt et al., 2012; Calof and Smith, 2012; Cuhls et al., 2012; Ramos et al., 2012; Borch et al., 2013; Meissner et al., 2013; Prior et al., 2013; Andersen and Rasmussen, 2014; Borodako, 2014; Vecchiato and Roveda, 2014; Güell and Collado, 2014; Mora et al., 2014; Remi, 2014; Rijkens-Klomp and Van Der Duin, 2014; Keller et al., 2015; Sokolova, 2015). Over the past decades, the concept has evolved greatly and is much different from the first attempts of forecasting. This gradual transformation is undoubtedly an integral part of the changes taking place in European capitalism, because foresight is feasible only in conditions offered by the market economy (McKinnon, 1991; Woo, 1994; Szubert-Zarzeczny, 1995; Svejnar, 2002; Hayo, 2004; Rhonheimer, 2012; Richardson, 2014). Within the foresight process it is necessary to consider many factors that influence the success: the structure of the system, the competitive context in which firms operate, the type of internal organization, innovation and the role of governments and their business practices.

The development of various sectors of the economy are important factors affecting the socioeconomic development. It includes political factors, but also social trends associated with the process of globalization. The latter have a particular impact on the development of tourism. In Poland, there was no possibility of using typical foresight stages of research and scientific tools, before the socioeconomic transformation (1989). The centrally planned economy did not allow for the analyzing of the needs of the market and decisions were taken without public consultation. Changing the system, economic and social reforms helped foresight studies gain popularity and importance in Poland. Up until 2013 there were four completed national foresight programs ("National Foresight Programme - implementation of the results" - a project funded by the Ministry of Science and Higher Education, 2011-2015; National Foresight Programme "Poland 2020" - a project funded by the Ministry of Science and Higher Education for 2006-2009; "Technology Foresight for Polish Industry - InSight 2030" launched in 2010 at the Ministry of Economy, "Foresight of human resources in modern economy" financed under the Human Capital Operational Programme) and about 45 regional and sectorial foresight projects (Awedyk, 2015). Unfortunately, none of the completed foresight projects were expected to carry out the research and scenario planning for the development of tourism.

The main objective of this paper is to present the changes in political and socioeconomic conditions after 25 years of transformation and how it provided a new methodology in tourism planning. It shows the possibilities offered by the use of the foresight process in planning the development of tourism in Poland. Since one of the main foresight goals is to identify trends, the paper makes attempts to verify trends that occurred in Poland after 1989 and if they have now and will have in the near future influence on Polish tourism. The detailed objective is to characterize the systemic transformation and its impact on the tourism economy. This is a review paper where literature of the topic, legislation and strategic documents query is used. It also includes comparative analysis.

\section{Globalization vs systemic transformation and its impact on tourism in Poland after 1989}

Analyzing the future of tourism comes to the forefront of globalization processes as determinants of changes in the world. It can be assumed that these processes will continuously influence the market processes in the future. Globalization is defined as "making the world a long-term process of integrating a growing number of national economies across borders, through the extension and intensification of interconnections (investments, productions, trades, cooperation), resulting in a global economic system with high correlation and significant repercussions actions/ongoing even in distant countries" (Zorska, 1998). Undoubtedly, this process leads, on one hand, to the convergence of social processes, including lifestyles and on the other hand leads to the unification of economic processes. The diversity of international markets and in particular the different systems of social and cultural values, conditioned by history and tradition, differs in standard of living or economic development of individual countries, as well as specific legal, 
technical regulations, etc. force adaptation of the offered product to the specific requirements of the markets of individual countries. The changes of buyers' needs will depend on the future of globalization.

Globalization and tourism as a socioeconomic phenomenon are linked closely, because tourism has become a powerful tool of globalization (Nawrocka and Oparka, 2007). Basic aspects of globalization impact contemporary tourism, primarily (Bosiacki, 2006):

- the impact of globalization to the sector of demand; and

- the impact of globalization to the sector of supply.

The globalization of markets is based on the penetration of consumption patterns in a transnational scale, which creates so-called global consumer culture. Consumers who create this culture in a similar way associate the same value (symbols, brands, attitudes) with a specific location. The symptoms of globalization in the tourism sector are primarily: rise of global competition (an increase in the number of competitors in local markets, including the so-called big players, who are fighting for dominance in the relevant market), tendencies of enterprises to mega concentrate property and capital (rise of enterprise-organized group systems and hotel chains, focusing in various forms and with different ownership structures from a few to a few thousand individual enterprises), increasing cooperation between companies in the world (vertical and horizontal integration, mergers and strategic alliances), the development and use of advanced technologies in the field of information and communications - including internet (it manifests itself, inter alia, in the increase of mechanization and automation of many works carried out by staff at all levels in tourist enterprise, virtualization tour operators offers and building a network organizations). The globalization of the tourism sector is also reflected in the standardization offers of enterprises (Niezgoda and Markiewicz, 2011).

The influence of globalization on tourism in Poland can only be observed after 1989, when events occurred which resulted in economic freedom and a new policy, including the tourism policy of the state. In 1989 there was a fundamental change in political and socioeconomic conditions in Poland. Poland entered the path of transformation as did the first post-communist countries from Central and Eastern Europe. This change mainly included the political and economic systems. The main objective, namely, the introduction of democratic structures and mechanisms had to be achieved through market-oriented transformation of the entire economic system. This concerned both the legal system and opening the economy to foreign markets most of all for the privatization of trade, services and production enterprises (Chojnicki, 1990; Szlachta, 1993, 1994; Gorzelak, 1994, 1995a, b; Chojnicki et al., 1995; Bivand, 1996; Lodkowska-Skoneczna, 1996; Lodkowska-Skoneczna et al., 1996; Parysek, 1998a, b).

Market-oriented transformation also focused on tourism as one of the sectors of the economy. The opening of borders and passport system changes allowed tourists to travel freely around the world. However, the development of tourism has not only affected, and will affect, the mechanisms related to the change of the political system, but also the demographic and social changes taking place at that time in Poland.

\section{Changes in the state tourism policy}

In socialism the state largely decided about the way of society's holidays. The socialist industrialization led to the development of large industrial plants, especially in heavy industry, which were obliged to have a company holiday resort. The constitutionally guaranteed right of all citizens to relax gave tourism the quantitative rather than qualitative character and social mechanism to verify the tourism product worked in a very limited scale. The consumer-hiker did not have freedom of choice, and tourism goods manufacturers forced selection techniques for producing a predetermined type of product (Awedyk, 2009).

In the centralized political and economic system, tourism policy stakeholders were not able to actively influence specific legal and organizational solutions for the real need of goods and tourism services for the population due to the monocentric type of social scheme based on a socialist system. After 1989 new solutions were implemented that completely eliminated the previous concept for the development and functioning of Polish tourism. They led to full compatibility 
between the real needs of society in terms of tourism consumption and functioning in a new economy market tourism industry (Szubert-Zarzeczny, 1995).

Before 1989, the ruling party's political program, in which tourism was one of the social achievements, perpetuated the attitudes of many social groups to the widespread use of goods and tourism services. After 1989, political parties, trying to stimulate and transform the economic system did not take into account in their assumptions programming capabilities to ensure universal participation in tourism of Polish society. Therefore, in the period of socioeconomic transformation there were changed expenditures on tourism in the general consumption of the population. Tourism has become a part of the state economic policy and no longer an element of social policy, as it was before 1990.

The process of Polish socioeconomic transformation was also affected severely by external political events, which together with the events in the country had decided on the transformation of the tourism economy, and also changed the character of tourism policy in this period. The collapse of the Soviet Union and adopted ion of the economic policy within the Balcerowicz Plan, introduced by the then Deputy Prime Minister and Minister of Finance (1989-1991) Leszek Balcerowicz, led to a sharp increase in the number of arrivals of ex-Soviet citizens to Poland, primarily not for reasons of tourism. Similarly, the reunification of Germany and the establishment of the Visegrad Group (an informal regional form of cooperation between the four countries of Central Europe - Poland, Czech, Slovakia and Hungary connected not only by the neighborhood and similar geopolitical conditions, but above all a common history, traditions, culture and values; the idea behind the creation of the V4 was to intensify cooperation in the field of building democratic state structures and a free market economy in the longer term participation of the European integration process; founded in February 15, 1991) influenced a strong "penetration" of Polish border areas. All of these arrivals were recorded as tourist traffic but in fact were often the target of trade or even smuggling. These arrivals inadvertently led to the application of new solutions in the tourism economy. The relationship between the transformation of the tourism economy and the systemic transformation mainly demonstrated in that the impact of the external environment led to the adoption of specific solutions, which then created its relationship during the transformation in tourist economy. Government policy rarely is conducive to tourism development, so during the transformation period the main task of tourism policy was anticipating changes in general economic policy of the government what in effect guided to changes in tourism (Szubert-Zarzeczny, 1985; Theuns, 1993). It is important to remember the role of the state in tourism before 1989 and the need to change the nature of the impact of tourism policy on the processes taking place in the tourism economy in the changed political and economic conditions.

\section{State interventionism and decentralization of power in tourism economy}

During the transformation period, the nature of the post-socialist state intervention was one of the most important elements of the entire process and it influenced the course of the reform. The transfer of economic power to lower levels of government was possible only in condition of the existence of the free market and private property. Since the previous political system had a high degree of centralization, the transformation required the existence of a separate entity that would be able to intervene in the political and economic processes. Such an entity could be only the unit state administration. With regard to the tourism transformation this role was taken by the Office of Physical Culture and Tourism established in 1991.

The initial phase of transformation created the conditions to develop the outline of a future tourism model in Poland. The proposed changes were a reflection of the economic policies introduced in 1990 and they contained some possibility of state intervention in tourism during the transitional period, which was to ensure the synchronization of activities of particular types of the tourism product. The production capacity of particular segments producing this product was differential in time and space. It should be remembered that in tourism there is a strong overlap of various forms of ownership and levels of management. The transformation helped to change the passive character of the socialist state tourism policy by increasing the activity of entities (Szubert-Zarzeczny, 1995). If there are conditions for an active tourism policy, and developed institutional organizations that can provide the necessary activity in this area, it means that the 
necessary components and solutions are introduced to the government's economic policies to support the development of the tourism economy (Szubert-Zarzeczny, 1995). Such conditions did not exist in Poland before transformation.

After 1989, the tourism economy very quickly used the economic freedom and decentralization of power. First introduced were changes in ownership relations, including privatization and restitution of national property. "Small privatization" (started by Balcerowicz plan), gave the greatest effects in relation to the tourism activities of tour agencies and tour operators as well as in the sector of tourism supply, in trade, catering and recreation services. However, the law on privatization from 1991, dealt with large state-owned enterprises which also included state-owned tourist companies, such as "Orbis", "Sports-Tourist", provoking strong resistance from the employees of these companies to the privatization methods.

The direction of the tourism transformation was also influenced by political - economic concepts of leading Poland to association with the European Union. The European Agreement of December 1991 created some of the standards governing the cooperation in the field of tourism between Poland and European Union countries. Article 88 of the agreement appointed tasks which include, among others: reorganization of Polish tourism, to lay the foundation of an innovative tourism industry, to create a modern and functional tourism infrastructure, to organize international marketing for promoting selected Polish regions as tourist centers, the reorganization of the central and regional administration, systematic promotion of selected tourist regions and harmonization of legislation with the provisions in force in the tourism economy of EU countries. Also, the aid program (PHARE) had been developed for Poland, which was implemented in tourism within the sub-programs Tourin I, Tourin II and Tourin III. Help for Poland under the PHARE program expressed primarily in consulting with Western European experts in the field of tourism policy, economics, law, etc. The role of tourism policy, including in particular the Office of Physical Culture and Tourism, was based on a significant stimulation of these processes, although the effects of the stimulation were limited initially (in the preparative phase of transformation) to organize different kinds of training and development of expertise by Western and domestic experts on tourism. (Zbieć, 1994).

In the second half of the 1990s and especially after 1999, there has been a fundamental change in the conditions of the functioning of Polish entities concerning politics and tourism economy. This was due to the progress and nature of the market system reforms. In fact there was an exhaustion of simple reserves of tourism development as a quantitative increase in crossborder traffic, which was related to an increase in unregistered trade turnover, positively influencing country's balance of payments. This has been used in tourism policy as an argument justifying the large role of tourism in the Polish economy. With the development of market relations there took place the equalization of prices between Poland and neighboring countries (especially Germany and the Czech Republic) that limited cross-border trade. As a result, there was a new challenge for tourism policy entities (especially for the national office of tourism) associated with the change of conducting in Polish tourism marketing strategy. It became necessary to precisely recognize conditions, economic and non-economic factors that determine the future development of tourism in Poland. Also of great importance were the economic policies of neighboring countries, carried out in border areas, whose aim was to increase competitiveness and improve trade turnover of German and Czech economic entities operating in these areas (Szubert-Zarzeczny, 2001).

\section{Tourism companies in a market economy}

One of the elements of the "market" under socialism was a quasi-tourist market which, although had not held great importance in the whole of the evolving economic relations in a socialist economy, but could very quickly assimilate the majority of changes or market-oriented innovations made before 1989. In fact, tourism was this sector of the economy (socialist), which had a rudimentary form of private property and was operated by a limited market mechanism. To a greater extent, in comparison with other areas, were used, e.g. advertising and tourist information, as well as some elements of the marketing strategy (Gołembski, 1980). In addition, the comparison with other areas of services, the regimentation of tourist services was negligible. 
In the first period of political transformation in Poland, the functioning of tourist enterprises was not governed by any specific legislation. Applicable in previous years, provisions had been repealed and in the beginning of the 1990s was characterized by a complete legal chaos in the tourism market. The need to issue regulations on the tourism market was caused by the need to adjust Polish law to EU standards. In 1992, numbers of regulations were reviewed in terms of their impact on the development of the tourism economy. The review provided the basis to find that the most urgent area in tourism to regulate were the rules for tourist services, especially in terms of legal protection of consumer interests, and to align these standards of providing services to the European standards and principles. In signing the Association Agreement with the European Union, Poland introduced of European standards of legal consumer interests protection and European standards of tourist services. A watershed year was 1997, when a law was passed on tourist services (The Act of 29 August 1997 on tourist services. Uniform text. U. of 2004, No. 223, item 2,268, No. 273, item in 2,703 and 2,005, No. 175, item 1,462). This law has become a fundamental piece of legislation regulating the operation of the market's basic tourism enterprises, which are travel agencies and hotel facilities. Moving into Polish law the provisions of the Council Directive of 13 June 1990, in its assumptions, intended to protect customers of travel agents on the package holidays and tours (Council Directive of June 13, 1990 on the package tours, holidays and trips, 90/314/EEC).

\section{Free passports use and visas abolition}

Until 1989, Polish citizens had no possibility of free passport use. They were issued by the Regional Militia Headquarters on the basis of the relevant permit and after the trip returned back. Since 1990, a passport is a document issued for ten years, by hand and stored in the house. The gradual opening of the borders occurred in the early 1970s. It was necessary to introduce such legislation, which would allow the control of foreign trips by the state authorities. This was necessary in the conditions of the undemocratic political system, non-removable currency deficiencies and an economy that ruled at that time in the country.

Another very important factor in Polish tourist traffic was the abolition of the visa requirement for Polish citizens to other European countries and certain countries in the world. Since May 1, 2004 visas against Polish citizens were completely abolished for entry into the European Union and European Economic Area - regardless of the purpose and duration of stay. Basis for visa-free movement within the European Union layout were contained in Schengen on June 14, 1985. It enacts one of the fundamental freedoms on which the European Union is founded - "freedom of movement." Currently, the Poles are required visas to 102 countries of the world (Zasady wjazdu obywateli polskich do poszczególnych państw, 2015).

\section{Convertibility of the zloty and the ability of foreign currency purchase}

The development of outbound tourism in Poland was also influenced by the government's decision regarding the convertibility of the zloty. Since 1960, the need for a "hard currency" made it difficult to travel to Western Europe, and solidified tourism within the countries of Central and Eastern Europe (within the Comecon bloc). In a time when the purchase of "non-socialist" countries currency was possible, Poles changed geographical directions of travel.

Before 1989 Poles were traveling combining pleasure of visiting another country with earning money. A significant part of trips made by Poles, especially to the countries of "second payment zone" (those countries in which the Polish zloty currency was not convertible), represented trips associated with taking up employment legal or illegal. Legal work was possible in our friend's countries (Libya or Iraq), illegally in restaurants, construction sites, farms, plantations and factories in Britain, France, Germany or Sweden. A large part of tourists traveling abroad in the 1960s, 1970s and 1980s were engaged in trade. In the era of nonconvertibility of Polish zloty, "allocation of 100 or 130 US dollars" and "books of monetary union" such trade was essential to make a trip ever come to fruition. In many cases, trips had become a way to survive the crisis in which more and more the society was plunged during the centrally controlled economy. In any case, the possibility of reaping financial benefits from trips before the revolutionary events of 1980-1981 significantly expanded the geographic 
scope of Polish trips (Podemski, 2001). It is worth emphasizing that greater freedom in movement compared to residents of other socialist countries, allowed to satisfy this part of the demand, which could not be met under the deficiencies of goods market. On one hand, tourism was a part of the social area, on the other hand, due to the economic failure of socialism, was a way to get some cash resources (foreign currency gained during the arrivals of foreigners), so necessary to the state.

\section{Opening of the Polish market for foreign travel companies}

The share of foreign capital in the Polish economy before 1989 was negligible. Foreign investment did not fit into the framework of the socialist system, propagating Polish self-sufficiency and the idea of a civilization race with the West. In this issue, a breakthrough has been made only with the transformation of the political system. There was created the legal framework for the functioning of the free market, including the scope of its regulation also deals with issues on the Polish market participation of foreign entrepreneurs. The basic importance had the law of December 23, 1989 on economic activity (today not binding, repealed with effect from January 1, 2000 the new Act Business Activity Law), which introduced the principle of freedom to conduct a business. The provisions of that Act (and its successor, the current) allowed foreign entities to open branches and representative offices in Poland. Foreign businesses participated in the Polish economy and by companies with foreign participation (joint venture) on the basis of the Law of June 14, 1991 (repealed in 2000). Foreigners could also be partners of commercial companies (based on the provisions of the Commercial Code first, and now - from January 1, 2001 - the Commercial Companies Code). After joining the European Union, citizens of the Member States, subject to the adoption of an identical solution on the Polish citizens by the State, may undertake and pursue economic activity on the same terms as Polish entities.

\section{Enrichment of certain social groups (the financial elites)}

Initiated in 1989 the process of transformation in Poland, led not only to major political and socioeconomic changes but also many changes in the structure of society. One of the most important changes is the emergence of new social elites. Of course, the biggest and most spectacular transformations related to the political elite, which fundamentally changed not only the composition and the structure of ruling elite, but also the relationship between the elite and the rest of society. Much smaller changes were observed in other social elites (cultural, academic) which results from the fact that the requirements for candidates and recruitment mechanisms for these elites are fundamentally different than for the ruling elite.

Polish financial elites had begun to form in Poland only recently. Basically, their existence had been noticed for only a few years. The process of creation is a bit different than usual because it is characterized by relatively low levels of inheritance fortunes. Currently, the greatest number of affluent Poles are people who carry out business activities (in the broad sense), founded and operating with new economic and business opportunities existing after the political system changes. As it is known, wealth is the most important factor determining the level and structure of tourist activity (Alejziak, 2001). These people constitute now, and will constitute in the future, a social group which is the most common customer of travel agencies offering sightseeing trips and leisure in countries of other continents.

\section{Social trends on tourism market}

The general trend affecting consumer behavior in the market, and thus on the development of various sectors of the economy is the development of societies, which makes citizens want to be wealthier, better educated and more experienced. These characteristics are associated with increasing certainty as to their own needs and aspirations, also in relation to the tourist offer (Niezgoda, 2010). The complexity of the phenomenon of tourism and the broad spectrum of needs underpinning the emergence of tourism demand gives rise to an increasing number of market segments in terms of marketing (Franch et al., 2006) and types of tourists, in a broader social significance. 
Another trend typical of the tourist market is individualization which results in tourists looking for new packages of services and types of relaxation. This trend may bring about certain tourists' aversion to famous venues and resorts. This is because tourists know these venues and will be looking for their own sets of services ("build their own holidays"). Searching for a tourism offer, single-handedly, results in the growing significance of the internet in promoting regions. As an increasing number of individual tourists resort to the internet, their decisions about the destination and the services depend on the offer's online availability as well as other consumers' opinions (Niezgoda, 2013). The tourism market is very susceptible to changes brought about by the internet. An observation of buyers' behavior, including e-readiness, inclines tourist agencies to intensify online activities. Research into the Polish tourist industry has revealed that 99 percent of tourist operators use the internet on a daily basis (Kachniewska et al., 2012).

An important trend resulting from the general processes of globalization is the global standardization, which makes a traditional reference group, such as job or family will lose their importance. A sense of identity is more and more often achieved through consumption or belonging to a community adapted. "Adapting community" means that the consumer reference group will constitute any social group that learns through a variety of media and means of communication (Bieger and Laeser, 2005). Standardization will mean the modern tourist will be increasingly aware of the possibility to meet their own needs and their own requirements resulting from the global service standards (Niezgoda, 2010). It is important to remember about the dialectical nature of globalization. Standardization is characterized by the progressive unification of lifestyles and consumption patterns, and individualization involves a noticeable increase in individual customer requirements. Standardization does not preclude individualization. An example might be the hotel industry, where tourists require a specific standard of rooms (related to globalization), while at the same time expect customized services of catering or additional services to meet their needs (Niezgoda, 2013). A tourist may purchase a standard package of services yet in the final destination he/she may look for a diversified offer, for example an opportunity to purchase local products, take part in a trip organized by a local agency, take up a fashionable sports discipline etc. One could therefore assume that as a result of general globalization, individualization processes are at the same time confronted with the growing significance of world standardization (Niezgoda, 2013).

During research into tourist demand, the buyers' increasingly different ways to satisfy the needs and requirements were noticed which may trigger off more involvement in search and exchange of information as well as creation of a tourism product. Increase in affluence leads to enhanced individual quality of life. Due to new technologies and the progress of the internet tourists tend to manage their time more independently and more frequently decide to organize their holidays individually. Tourists want to use time "effectively." This means that when they are on holidays, they want to see and experience as much as possible. People tend to maximize experience per time unit (Niezgoda, 2013). Sometimes, it means seeing or doing more things. On the other hand tourists may prefer to escape and relax enjoying deeper their time during the holiday (a classic example is the slow tourism movement).

Contemporary consumers tend to care more about their health; this is related to environmental behavior. As a result of the growing environmental awareness, a new consumer has emerged, willing to purchase ecological good and services, to change his/her lifestyle, habits and consumption models in order to protect the natural environment. An active internet user, the modern tourist who is highly aware of environmental issues may encourage others to be environmentally friendly and communicate to tourist service providers the need for an offer compliant with the requirements of environmental protection (Niezgoda, 2011).

Another important trend in the future will be the growing importance of seniors' segment in the tourism market and the consequent increase in the importance of regular customers (Śniadek, 2006; Dann, 2000; Mansvelt, 1997). Tourists 55+ are people with extensive experience and with knowledge of their own needs. Before the political transformation in Poland, the financial situation of the elderly and the above described legal and political limitations hampered and often made trips impossible for those tourists. Today it is a growing 
segment, which will result in it becoming even more important in the future. It should also be emphasized that this is not a uniform segment, which in the future will be a challenge for the marketing of tourist services. The above described general social trends affect now and will affect in the future the specific travel behavior.

\section{Trends in Polish outbound tourism}

Before forecasting the future of tourism in Poland it is important to analyze the changes in the dynamics of tourism flow. In the years 1993-2013, tourist movements attended by an average 17 million Poles. The highest number of travelers, 19.5 million, was recorded in 1999. This was higher than the minimum in 1994 by six million people (Makowska-lskierka, 2014). To this threshold value were similar results in 2011 (13.9 million). The largest increase in number of participants in the entire tourist movements was recorded in 1994-1997 and 2011-2013. Lasting from the beginning of the twenty-first century the downward trend intensified in the years 20032004 (difference of 1.7 million tourists) and then was halted what coincided with the Polish accession to the European Union. A sudden drop of total tourist trips (a difference of 0.8 million people) occurred in 2010-2011. The most Poles decided for a trip abroad in the years 2007-2009 (six million in 2008). These were primarily migration to the UK and Ireland. In 2010-2011, as domestic trips, those trips recorded a decrease, but in 2013 bounced back to 5.5 million.

In the last two decades in tourist trips participated on average, 53 percent of Poles (aged 15 and over). Maximum covering the 63 percent of the population accounted in 1997 and 1999, with a minimum representing 43 percent recorded in 2011. (Makowska-Iskierka, 2014). In the period 1994-2013, the greatest portion of the population participating in foreign travel, left in 2008 (18.0 percent) and the lowest in 1994 (9.5 percent) and 1998 (10 percent). In these years, Poles were primarily interested in domestic travel which at that time reached their highest ratings. Conducted in 2014, commissioned by the Ministry of Sport and Tourism (Janczak and Patelak, 2014), accurate analysis regarding Poles' participation in tourism in 2013 allows to draw the following conclusions:

- Increases in the level of participation in relation to long-term trips (over five days) both domestic and foreign; for short-term trips abroad participation of Poles remains unchanged.

- Trips abroad are still rare and most elite; travel mainly business owners (36 percent), salaried employees and students (about 22 percent), also well-off people with higher education.

- Biggest tourism movement flow falls on the third quarter of the year (42 percent); the second to the popularity is Christmas and New Year period and the period of Winter; the least active for traveling abroad were during the months of April and November.

- The main directions of trips are Germany (close distance, a significant number of Polish migrants live there, commercial cooperation), UK, Italy, Czech Republic, France, Spain; while there was a decrease in trips to Ireland, Lithuania, Bulgaria and Denmark.

- The most common objective of trips abroad in 2013 were leisure, recreation and holidays, they accounted for as much as half of all trips ( +6 pts. percent $y / y)$, while the share of VFR travels fell $(-2 \mathrm{pp} . \mathrm{y} / \mathrm{y})$, also decreased the percentage of business trips to a level of 26.5 percent (from 28 percent in 2012).

- For the purposes of leisure, recreation and holidays Poles usually travel to (in order of popularity), Croatia, Italy, Germany, Spain, Greece, Slovakia, Turkey, the Czech Republic and France. In order to VFR Poles traveled mainly to Germany and the UK (a half of all visits) and to Norway, the Netherlands, France and Ukraine; for business: Germany (one-fourth of all trips), the Netherlands, Italy, France, Norway, UK.

- Poles traveling around the country most often visit cities; for long-term trips almost half of trips were combined with a visit to the city; for short-term - up to 80 percent; next destination by popularity for long-term trips are mountain areas with the same success as rural areas (both 29 percent), short trips take place more often to the countryside (36 percent) than in the mountain areas (22 percent); every fourth long-term trip and one in ten of short trips are journeys to the seaside. 
- Going abroad, Poles mostly traveled by plane (42 percent of responses), it was the means of transport which gained in popularity significantly (increase by 10 pts. percent compared to 2012) ahead of the car - the second most popular choice; car held 35 percent of the trips (less than a year ago by 4 pts. percent).

- Increase in the average spending (2012-2013 - more by 7 percent), incurred while traveling by 12 percent.

- Observing the expenses incurred on travel abroad in 2013, can be seen a clear relationship between the amount of expenditure and financial situation of tourists: those setting out their financial situation as good earmark for the trip on average 3,533 zł (883 EUR), but held relatively shortest travel, what else increased, more disparities in expenditures converting them per a day (353 zł/88 EUR); people with average financial status spend for the trip on average 2,206 zł (551 euros) and a day longer of traveling than the wealthiest, which gives 201 zł (50 EUR) per day; the worst-off opt for low-cost trips - 1,629 zł per person (407 euros), but spend most days on the road (13), so its daily cost is even lower - $125 \mathrm{zt}$ (31 EUR).

- The percentage of traveling seniors ( $\geqslant 65$ years) was in 2004 in Poland 20.7 percent, which on the background of many European countries does not look good; higher rates were gained in Czech Republic (26.2 percent), Slovakia (34.6 percent), Germany (40.8 percent), UK (49.7 percent), France (59.8 percent) and the Netherlands (61.2 percent) (Śniadek, 2007).

- In 2013 in tourist trips participated 49 percent of children aged up to 14 years, so 11 pts. percent more than in 2010; it means a return to the trend before 2010 (and even some improvement), when the participation of children in tourist trips were estimated at approx. 42-46 percent.

- Children primarily participate in domestic trips -43 percent, especially in long-term ones: in 2013, 31 percent of children aged up to 14 years participated in trips lasting a minimum of five days, and 20 percent in travels with at least one overnight stay, but not more than four days (three nights); in outbound tourism children's participation under the age of 14 years was 9.5 percent.

These statistics allow us to conclude that in the future the tourism market in Poland will grow in terms of both quantity and quality (clear segmentation of consumers and diversification of trips destinations). The knowledge of these important changes occuring in recent years in Polish tourists' behavior and treveling directions can be used in the scenario planning, what is one of the main elements of the foresight process.

\section{Foresight as the opportunity in development of tourism in Poland in present systemic conditions}

The phenomena that have affected tourism in Poland are multithreaded due not only to the legal, political and economic (economic transformation) but also social nature. The latter requires forecasts and anticipation of changes in order to make the best prediction of the future. Trends extrapolation makes it possible to write scenarios for the future and what helps best to prepare market operators for competitive activities. Therefore, foresight is an important instrument for such activities.

Foresight considers a future shaped by many complex and uncertain visions. It is assumed that the future is open and not predetermined (Güell and Collado, 2014). Forecasters tend to focus on a limited range of issues for which there is "hard data" in government statistics, and only by implication rely on the "soft" factors. In contrast to this approach, the same "soft" factors can be the foundation and an important element of foresight. That is why foresight uses mostly quality tools. Considering the fact that forecasting future events is associated with conducting research and analysis of data that are imprecise and vague, the choice of qualitative methods in the study of the future of tourism seems to be a good solution.

According to many authors (Martin, 1995; Gavigan and Scapolo, 1999; Güell, 2012; FOREN 2001), applying foresight to territorial solutions can be defined as the systematic, involved data collection and the creation of vision for the future based on current decisions and mobilizing 
common action of territorial scope. In this way foresight, as a research approach, takes place in which regional policy, strategic planning and future studies overlap. Foresight does not plan, does not define the current policy nor replaces current decision making. On the contrary, it complements these activities and increases their effectiveness.

It is important to mention, a foresight paradigm that is built around a practical approach to future planning, consists of finding many solutions and opportunities that should be introduced into the environment before it will be forced to do so. This means a different course of action: transition to analyze the "process" of creating possible scenarios for the future, rather than creating a specific "product" in the form of one version of the future events. The challenge of foresight is to see the structure of the future, not its actual content and the more details. In result such actions in consequences primarily are focused on networking and forums available for public debates. At this point, should also be pointed out the differences between forecasting and foresight. Forecasting imagines the future as a linear and unique process based on events from the past; the future is clearly predictable (Güell, 2012); assumes rather passive and descriptive form, studies and implements scientifically designed path of the future; is primarily based on quantitative methods and tools. Foresight predicts the future as a complex and uncertain vision; the future is open and uncertain; is uniquely active - checks how the consequences may lead the individual to change and what options for action will lead to the development of an alternative (desired) future; mostly uses qualitative methods and tools. A significant element distinguishing also the foresight of forecasting is the presence of the experts in the research process, who in the final stages assess achieved results. Above all, they express their views on elaborated scenarios for development of the area of research.

Markidas and Wheelwright (1987), reviewing various forecasting techniques stated that "depending on the methods used, various empirical studies have reached different conclusions" and that "no studies show no clear superiority of one method over another." He also considered that there is no single method that over time surpassed the others, and the appropriate method largely is dictated by forecasting horizon. This finding is also supported by Witt and Witt (1992, 1995) and Song et al. (2009), reaching exactly the same conclusion from his analysis on research methods used in tourism forecasting.

Analyzing future research methodology, in the context of used surveys techniques it allows three sources of typology that are taken in their implementation to be distinguished:

- forecasting - typically draws on formal models, such as econometric and demographic extrapolation;

- envisioning - draws on science fiction imagery and metaphors, historical analogy and incidents; and

- polling - conducted on media debates and expert knowledge, then used in scenario planning as a fundamental tool of foresight.

Most approaches to futures studies involve all three activities to some degree, even when they appear to emphasize a particular technique. For example, most econometricians and demographers use their own judgment and expectations to fine-tune their extrapolations.

Each activity requires special skills and appeals to a different kind of audience. Policymakers appear to prefer the quantified forecasts offered by extrapolation; futures for the general public often include creative visual or verbal imagery, and business and community groups often favor participative polling-based approaches (Cole, 2007). The emphasis across these activities, the mix of techniques used, and the overall approach used in any given futures study reflects a host of issues - for example the topics to be considered; the time scale, the orientation/perspective, philosophy/skills, etc., of the futurist(s); and the anticipated audience.

It seems that foresight can offer tangible benefits in planning tourism in Poland. First, it systematizes discussions on the future prospects of tourism development taking into account a wide range of factors, thus building consistent and credible visions of the future. After the political transformation it can be seen that the global trends and globalization also refer to the Polish reality and have wide impact for the tourism economy, but because of the history they appeared in Poland much later. This is undoubtedly a positive development which not only allows the use of 
good experiences and practices of economically developed countries, but also allows the use of already proven research techniques and tools that have worked in Western Europe. Despite the lack of experience and examples, issues related to the future scenarios creation, as well as foresight can provide a new quality in research on the development of the tourism market in Poland. As used in a wide range in foresight research qualitative methods do not need to be easier or less time-consuming than the quantitative ones. They are essential, because they help in identifying different factors than those which can be inspected by quantitative measurement, thus allowing them to be included them in the analysis. As a result, additional information can be obtained in relation to those obtained using conventional quantitative methods. It often happens that the detection of the phenomenon of qualitative methods process generates a quantitative study to determine its size or intensity.

Second, it helps to formulate realistic and innovative tourism strategies that can accept the views of many stakeholders, future not present needs and capabilities, and multi-layered vision of the future, which, particularly in the analysis of the development of tourism must take into account the element of risk, an unpredictable issue. In tourism, many important factors that determine the demand and supply are constantly changing. Sometimes, it turns out, the information that did not fit into in the standards of quantitative measures tests had a key role in the development of tourism. Hence, analyses regarding the future of tourism, are not very popular and rarely are the subject of academic interest. Today, however, modern techniques and methods of making research on the future, takes into account the subjectivity in making decisions, and this is essential in determining the future direction of tourism development. Planners need to learn how to be more sensitive to information that initially may seem insignificant, but really that's what they called "weak signals," they can dramatically affect the changes in culture, tradition, society and individual decisions taken. Planning the future, the identification of future trends may have positive anticipation in market changes what should help to avoid the element of surprise and loss, as well as become a determinant of competitiveness for tourism organizations or regions.

Third, in order to exchange and disseminate knowledge through practices of foresight, networks of experts are created among stakeholders and policy makers. In contrast to traditional planning processes, which typically have limited sectorial coverage, through the method of participation (participation in the project of many diverse partners representing different interest groups, as well as different areas of experts and (or) expertise), foresight is gradually building an integrated vision of a possible future. It is therefore an important addition to the established and traditional planning processes by supplementing them with new elements and values, strengthening local agents, and ensuring the legitimacy of territorial strategies.

Not used previously in the research on the development of tourism in Poland, the methodology of foresight can be a very useful tool in the scenario's planning. It should be noted, however, that the use of qualitative methods in scenario planning is quite widely used in many other fields of science research and strategies in the world, despite this forecasting still has little application in tourism. Tourism through its unique, changing character, globally, but also as far as possible regionally and locally can be appropriately formed. In a time of rapidly occurring changes, there is no possibility that linear projections based on statistical figures, which are now perceived as only probable, had a chance of success. Foresight however, belongs to a group of researches using complex and uncertain methods and tools. As it tries to anticipate the future with regard to numerous factors affecting its social, technological, economic, ecological and political aspects requires extensive research and expertise as well as the experience of participants.

Despite the above-mentioned clear advantages of foresight it may have some disadvantages, as it seems it will create problems in the implementation of its particular assumptions. In the first place, foresight cannot solve or overcome social, economic, environmental and political problems that affect the development of tourism both at national and regional levels. So far, in Poland, the traditional planning based on the belief that the use of expertise, in order to achieve specific goals, will guarantee effective and efficient management. Often these plans (strategies) do not take into account the diversity of local conditions or propensities to new situations that can suddenly turn out to be unpleasant surprises. Prognostics tend to focus on a limited range of issues for which there is "hard" data in government statistics, and only presumably rely on the 
"soft" factors. In contrast to this approach, the same "soft" factors may be an important element and the foundation of foresight.

Second, foresight cannot impose a consensus where there are deep disagreements between stakeholders' directions and development priorities. Disagreement and expectations among the participating partners can take place in case of loss of compliance objectives or vision for the future of the region or sector, but also in the context of building common results, which will then be implemented after the completion of the process. The tourism product is very complex, because its elements are offered by various entities (tourist and hotel businesses, local government, carriers). Success depends on their cooperation and common strategies of action. Unfortunately, very often the tourism market stakeholders have divergent goals and may give rise to conflicts. The concept, which enables the achievement of common objectives as sustainable development, said even in the most important piece of legislation in Poland, the Polish Constitution.

Third, foresight is not a fast means for the pressing problems because it requires lengthy analysis and to create a network of experts that does not bring immediate results. The literature clearly indicates that such projects should focus on the long-term period (national projects, where the far future includes a period of 15-30 years, while at regional level often can be analyzed for 10-20 years).

Finally, foresight requires some rules that may be difficult to implement in developing public institutions whose possibilities are rather small. Often, short-term factors, such as the establishment of the annual budget in territorial units, or the pressure of the elections are the main goal of the activities of public institutions, and this is undoubtedly a barrier to the much more important long-term planning.

\section{Conclusion and discussion}

The coming years will bring many changes in tourism and the way free time is spent. Predicting directions of development of tourism, both globally and regionally, has the potential to play an important role in increasing the benefits of tourism and alleviate problems associated with it. Planning the future, the identification of future trends and with the consequence anticipating changes in the market should help avoid the element of surprise and loss, as well as become a determinant of competitiveness for stakeholders. In dealing with uncertainty it is crucial to be creative and have the ability to quickly adapt to changes. The new conditions, requiring new solutions help to keep the rapidly changing economy in business.

Poland is the country in which the change of political conditions led to a fairly dynamic development of the tourism sector, to increase interest in outbound tourism and create the conditions to achieve these goals. There were situations and factors changing the operation's field of stakeholders in the tourism market. Therefore, it may be an excellent example of the necessity of foresight's use in order to avoid drastic changes of the business environment and the functioning of tourist regions.

Indicated relations were descriptive with attention to the social dimension of both the tourist movement as well as trends affecting consumer behavior. Of course, for a more detailed analysis of the described above phenomena, it would be worthwhile to consider the extrapolation of trends in terms of volume. However, it is a difficult task, because the statistics of tourist trips are not uniform with respect to different countries, and besides, it largely consists not only holidays (e.g. as described above shopping trips abroad after the opening of the borders in 1989). A major difficulty in collecting quantitative data are also the processes of European integration and the opening of borders, which prevents statistical control of border crossings. On the other hand, it is further proof of the need for a qualitative form of surveys of researchers that could describe the current state and future of the sector. Therefore foresight can be such a tool.

Analyzing the current external and internal factors, global, regional and local trends, tourism industry is able to anticipate and develop possible scenarios for the development of Poles' tourism. It is one of the essential conditions for a future, a positive functioning of the tourism economy. Important both for tour operators sending tourists abroad, as well as for traders offering holidays in Poland. Unfortunately, at the moment, in Poland, there is shown a complete 
lack of activity in preparing for the changes caused by global trends as well as the climate changes. The future scenarios for the development of tourism are now extremely important for mountain regions, where entrepreneurs focused on winter tourism, based on snow have no alternative offer condemning the region to a total defeat in the tourist world. It seems that to overcome institutional barriers, financial and socio-cultural process will be long and difficult. Unfortunately, even tourism regions in Poland could still be attractive for tourists, future scenarios for tourism development based on the needs and opportunities today are not being taken into account in local strategies. It should be emphasized that policies must be consistent at all levels of government of the country (Niezgoda, 2004). It should be aware that Polish society now has a much greater impact on the future than it did in the past. Very important is the ability to recognize signals that currently may seem insignificant, but in the end may become a powerful impulse to create new trends. Appropriate action means that the future is not one of the great unknown, but the result of actions of the government, tour operators and citizens.

The process of political transformation from a system based on a centrally controlled economy to a market economy in the 1980s and 1990s affected many countries in Central and Eastern Europe. Changes in Poland, which was the first in the region, gave a signal to other socialist countries for similar transformations, primarily in Hungary, Czechoslovakia, East Germany, Bulgaria and Romania. Fundamental shift resulted in significant differences in the existing structure of supply and demand on the tourism market, as well as diversification of motivations for traveling. The current legal and economic regulations, which are widely used in democratic countries, offer new opportunities both in techniques used in decision making and planning, as well as in setting goals that can be achieved. It is important to note, however, tourism development is based on values and attractions it may be very different in particular countries. Therefore, despite the similarity of political changes and tools for tourism development can proceed variously.

Foresight is one of such tools, what results from its main goals: anticipation, vision, participation, action and networking. Foresight foresees and plans in an organized and long-term way social, economic and technological needs and development. Clarifies leading strategic vision, which is an expression of the needs of society involved in the project. Foresight enables participation, which involves an active interactive methods of engaging and supporting the debate of various partners representing many interest groups. Thanks to the foresight detailed action plans it develops and implements strategic visions which present decisions can transform into the image of the future. It also creates a network to exchange ideas, opinions, experiences and specialist knowledge creating new social communities.

Undoubtedly, the opportunity that is offered now should be seized and new solutions should be used. Before now, in countries of the former socialist bloc most of them did not have the right and the conditions to exist. Foresight is the great offer to try.

\section{References}

Alejziak, W. (2001), “Aktywność turystyczna i rekreacyjna polskich elit finansowych”, Turyzm, Vol. 11 No. 1, pp. 25-42.

Andersen, P.D. and Rasmussen, L.B. (2014), "The impact of national traditions and cultures on national foresight processes", Futures, Vol. 59, June, pp. 5-17.

Awedyk, M. (2009), Pozaeuropejska turystyka poznawcza mieszkańców Polski w aspekcie przemian ustrojowych, Bogucki Wydawnictwo Naukowe, Poznań.

Awedyk, M. (2015), "Foresight jako potencjalna metoda modelowania kierunków ruchu turystycznego", in Durydiwka, M. and Duda-Gromada, K. (Eds), Przestrzeri w turystyce-znaczenie i wykorzystanie, Uniwersytet Warszawski, Wydział Geografii i Studiów Regionalnych, Warszawa, pp. 163-76.

Bieger, T. and Laeser, Ch. (2005), "Framework and developments with regard to leisure travel in mature Central European markets - results and implication based on a document review", Tourism Review, Vol. 60 No. 4, pp. 19-25.

Bivand, R. (1996), "Unravelling transformation process in Poland: local and regional differentiation since 1989", in Chatterij, M. and Domański, R. (Eds), Urban and Regional Management in Countries of Transition, PWN, Warszawa, pp. 221-38. 
Borch, K., Dingli, S.M. and Jorgensen, M.S. (2013), Participation and Interaction in Foresight: Dialogue, Dissemination and Visions, Edward Elgar Publishing, Surrey.

Borodako, K. (2014), "Key foresight attributes of tourism companies in the city of Krakow and the region", International Journal of Tourism Research, Vol. 16 No. 3, pp. 282-90.

Bosiacki, S. (2006), "Wpływ globalizacji na stan i perspektywy rozwoju polskiej turystyki", in Raszka, B. and Bosiacki, S. (Eds), Gospodarka turystyczna w XXI wieku. Globalne wyzwania i zagrożenia, Wydawnictwo AWF, Poznań, pp. 41-9.

Calof, J. and Smith, J.E. (2012), "Foresight impacts from around the world: a special issue", Foresight, Vol. 14 No. 1, pp. 5-14.

Chojnicki, Z. (1990), "The anatomy of the crisis of the polish economy", in Kukliński, A. and Jałowiecki, B. (Eds), Local Development in Europe: Experiences and Prospects, Regional and Local Studies, Vol. 5, University of Warsaw, Warszawa, pp. 55-88.

Chojnicki, Z., Czyż, T. and Parysek, J. (1995), "Transformations and dilemmas of the polish economy", in Carter, F.W. and Maik, W. (Eds), The Process of Socio-Economic Transformations in Central and Eastern Europe after 1989, Turpress, Toruń, pp. 7-26.

Coates, J.F. (2010), "The future of foresight - a US perspective", Technological Forecasting and Social Change, Vol. 77 No. 9, pp. 1428-37.

Cole, S. (2007), "Dare to dream: bringing futures into planning", Journal of the American Planning Association, Vol. 67 No. 4, pp. 372-83.

Colwell, K. and Narayanan, V.K. (2010), "Foresight in economic development policy: shaping the institutional context for entrepreneurial innovation”, Futures, Vol. 42 No. 4, pp. 295-303.

Cuhls, K., Blind, K. and Grupp, H. (2012), Innovations for our Future: Delphi'98: New Foresight on Science and Technology, Springer-Verlag, Berlin.

Da Costa, O., Warnke, P., Cagnin, C. and Scapolo, F. (2008), "The impact of foresight on policy-making: insights from the FORLEARN mutual learning process", Technology Analysis \& Strategic Management, Vol. 20 No. 3, pp. 369-87.

Daffara, P. (2011), "Rethinking tomorrow's cities: emerging issues on city foresight", Futures, Vol. 43 No. 7 , pp. 680-9.

Dann, G. (2000), "Senior tourism”, Annals of Tourism Research, Vol. 28 No. 1, pp. 238-40.

Destatte, P. (2010), "Foresight: a major tool in tackling sustainable development”, Technological Forecasting and Social Change, Vol. 77 No. 9, pp. 1575-87.

FOREN (2001), A Practical Guide to Regional Foresight, Foresight for Regional Development Network, European Communities, Seville.

Franch, M., Martini, U., Novi Inveradi, P.L. and Buffa, F. (2006), "From reconstruction and analysis of tourist profiles to some suggestions to destination management - an empirical research to the Dolomites Area", Tourism Review, Vol. 61 No. 2, pp. 30-7.

Gavigan, J. and Scapolo, F. (1999), "Comparison of national foresight exercises", Foresight, Vol. 1 No. 6, pp. 495-517.

Georghiou, L., Harper, J.C., Keenan, M., Miles, I. and Popper, R. (2008), The Handbook of Technological Foresight. Concepts and Practice, Edward Elgar Publishing, Inc., Northampton.

Gołembski, G. (1980), Warunki zastosowania marketingu w turystyce w gospodarce centralnie planowanej, AE, Poznań.

Gorzelak, G. (1994), "Regionalne oblicze polskiej transformacji w latach 1995-2005", in Mync, W.A. and Jałowiecki, B. (Eds), Przedsiębiorczość i prywatyzacja, Vol. 168, Biuletyn KPKZ PAN, Warszawa, pp. 9-64.

Gorzelak, G. (1995a), "Regionalne uwarunkowania transformacji ustrojowej", in Jałowiecki, B. (Ed.), Współczesne problemy rozwoju regionalnego, Uniwersytet Warszawski, Katedra UNESCO Trwałego Rozwoju, Warszawa, pp. 63-92.

Gorzelak, G. (1995b), Transformacja systemowa a restrukturyzacja regionalna, Uniwersytet Warszawski, Katedra UNESCO Trwałego Rozwoju, Warszawa. 
Güell, F.J.M. (2012), "Foresight as an innovative tool for designing tourist destinations", Conference of the International Forum on Urbanism, 6th Conference of the International Forum on Urbanism (IFoU): TOURBANISM, Barcelona, January 25-27, pp. 1-11.

Güell, F.J.M. and Collado, M. (2014), "Foresight in designing sun-beach destination”, Tourism Management, Vol. 41 No. 2014, pp. 83-95.

Hayo, B. (2004), "Public support for creating a market economy in Eastern Europe", Journal of Comparative Economics, Vol. 32 No. 4, pp. 720-44.

Hilbert, M., Miles, I. and Othmer, J. (2009), "Foresight tools for participative policy-making in inter-governmental processes in developing countries: lessons learned from the eLAC policy priorities Delphi”, Technological Forecasting and Social Change, Vol. 76 No. 7, pp. 880-9.

Janczak, K. and Patelak, K. (2014), Uczestnictwo Polaków w wyjazdach turystycznych w roku 2013, Ministerstwo Sportu i Turystyki, Aktiv Group, Łódź.

Jemala, M. (2010), "Evolution of foresight in the global historical context”, Foresight, Vol. 12 No. 4, pp. 65-81.

Kachniewska, M., Nawrocka, E., Niezgoda, A. and Pawlicz, A. (2012), Rynek turystyczny. Ekonomiczne zagadnienia turystyki, Oficyna Wolters Kluwer, Warszawa.

Keller, J., Markmann, Ch., Heiko, A. and von der Gracht, H.A. (2015), "Foresight support systems to facilitate regional innovations: a conceptualization case for a German logistics cluster", Technological Forecasting and Social Change, Vol. 97 No. 2015, pp. 15-28.

Könnölä, T., Scapolo, F., Desruelle, P. and Mu, R. (2011), "Foresight tackling societal challenges: impacts and implications on policy-making”, Futures, Vol. 43 No. 3, pp. 252-64.

Lodkowska-Skoneczna, A.G. (1996), "Wpływ procesów transformacji na zróżnicowania regionalne w Polsce", Zróżnicowania regionalne jako wyzwanie strategiczne polityki rozwoju regionalnego Polski. Regionalne i lokalne uwarunkowania i czynniki restrukturyzacji gospodarki Polski, Fredrich Ebert Stiftung, Katowice.

Lodkowska-Skoneczna, A.G., Pyszkowski, A. and Szlachta, J. (1996), Rozwój regionalny Polski. Raport diagnostyczny, Zespół Zadaniowy ds. Rozwoju Regionalnego w Polsce, Katowice.

Loveridge, D. (2009), Foresight: The Art and Science of Anticipating the Future, Routledge, New York, NY.

McKinnon, R.I. (1991), "Financial control in the transition from classical socialism to a market economy", The Journal of Economic Perspectives, Vol. 5 No. 4, pp. 107-12.

Makowska-Iskierka, M. (2014), "Uczestnictwo Polaków w wyjazdach krajowych - tendencje i zmiany w latach 1993-2013”, in Włodarczyk, B. (Ed.), Przeszłość, Teraźniejszość i przyszłość turystyki. Warsztaty z Geografii Turyzmu, Vol. 5, Wydawnictwo Uniwersytetu, Łódzkiego, pp. 181-95.

Mansvelt, J. (1997), "Working at leisure: critical geographies of aging”, Area, Vol. 29 No. 4, pp. 289-98.

Markidas, S. and Wheelwright, S.C. (1987), The Handbook of Forecasting: A Manager's Guide, 2nd ed., Wiley, New York, NY.

Martin, B. (1995), "Foresight in science and technology", Technology Analysis and Strategic Management, Vol. 2 No. 7, pp. 139-68.

Meissner, D. (2012), “Results and impact of national foresight-studies”, Futures, Vol. 44 No. 10, pp. 905-13.

Meissner, D., Gokhberg, L. and Sokolov, A. (2013), Science, Technology and Innovation Policy for the Future: Potentials and Limits of Foresight Studies, Springer, New York, NY.

Mora, O., Banos, V., Regolini, M. and Carnus, J.-M. (2014), “Using scenarios for forest adaptation to climate change: a foresight study of the Landes de Gascogne Forest 2050", Annals of Forest Science, Vol. 71 No. 3 , pp. 313-24.

Nawrocka, E. and Oparka, S. (2007), Hotel w XXI wieku. Zarządzanie w warunkach globalizacji, Edukacja, Wrocław.

Niezgoda, A. (2004), "Problems of implementing sustainable tourism In Poland", Poznań University of Economics Review, Vol. 4 No. 1, pp. 30-42.

Niezgoda, A. (2010), “Nowe trendy w popycie - wyzwanie dla obszarów recepcji turystycznej”, in Tanaś, S. (Ed.), Nauka i dydaktyka w turystyce i rekreacji, Łódzkie Towarzystwo Naukowe, Łódź, pp. 21-34. 
Niezgoda, A. (2011), "The role of environmental knowledge, attitudes and initiatives in the development of tourism product”, Tourism, Vol. 21 Nos 1-2, pp. 33-9.

Niezgoda, A. (2013), "Prosumers in the tourism market: the characteristics and determinants of their behavior", Poznań University of Economics Review, Vol. 13 No. 4, pp. 130-41.

Niezgoda, A. and Markiewicz, E. (2011), "Autostrada jako czynnik zmian kulturowych w produkcie turystycznym”, in Gołembski, G. (Ed.), Wpływ autostrady Warszawa-Berlin na rozwój turystyki w regionie, Wydawnictwo Państwowej Wyższej Szkoły Zawodowej w Sulechowie, Sulechów, pp. 94-101.

Öner, M.A. (2010), "On theory building in foresight and futures studies: a discussion note", Futures, Vol. 42 No. 10, pp. 1119-30.

Parysek, J. (1998a), "Efekty procesu transformacji społeczno-gospodarczej w Polsce. Bilans okresu 1989-1996", in Parysek, J. and Rogacki, H. (Eds), Przemiany społeczno-gospodarcze Polski lat dziewięćdziesiątych, Bogucki Wydawnictwo Naukowe, Poznań, pp. 25-45.

Parysek, J. (1998b), "The spatial dimension of the process of socio-economic transformation (in the first 6 years)”, in Domański, R. (Ed.), Emerging Spatial and Regional Structures of an Economy in Transition, Vol. 168, KPZK PAN, Studia Regionalne, pp. 33-58.

Podemski, K. (2001), “Udział Polaków i Polski w międzynarodowych podróżach”, in Golka, M. (Ed.), Nowe style zachowań, Wydawnictwo Fundacji Humaniora, Poznań, pp. 198-213.

Popper, R., Keenan, M., Miles, I., Butter, M. and Sainz, G. (2007), "Global Foresight Outlook", available at: www.inovasyon.org (accessed May 20, 2015).

Prior, T., Daly, J., Mason, L. and Giurco, D. (2013), "Resourcing the future: using foresight in resource governance", Geoforum, Vol. 44, March, pp. 316-28.

Ramos, J., Mansfield, T. and Priday, G. (2012), "Foresight in a network era: peer-producing alternative futures", Journal of Futures Studies, Vol. 17 No. 1, pp. 71-90.

Remi, B. (2014), "Innovation systems dynamics and the positioning of Europe. A review and critique of recent foresight studies", Foresight, Vol. 16 No. 2, pp. 126-41.

Rhonheimer, M. (2012), "Capitalism, free market economy, and the common good: the role of the state in the economy", Free Markets and the Culture of Common Good, Ethical Economy, Vol. 41, pp. 3-40.

Richardson, J. (2014), "ICSU foresight analysis, international science in 2031 - exploratory scenarios", Foresight, Vol. 16 No. 2, pp. 192-5.

Rijkens-Klomp, N. and Van Der Duin, P. (2014), "Evaluating local and national public foresight studies from a user perspective", Futures, Vol. 59, June, pp. 18-26.

Śniadek, J. (2006), "Age of seniors - a challenge for tourism and leisure industry", Studies of Physical Culture and Tourism, Vol 13, Supplement, pp. 103-6.

Śniadek, J. (2007), "Konsumpcja turystyczna polskich seniorów na tle globalnych tendencji w turystyce”, Gerontologia Polska, Vol. 15 Nos 1-2, pp. 21-30.

Sokolova, A. (2015), "An integrated approach for the evaluation of national foresight: the Russian case", Technological Forecasting and Social Change, Vol. 101, December, pp. 216-25.

Song, H., Witt, S.F. and Li, G. (2009), The Advanced Econometrics of Tourism Demand, Routlege, New York, NY.

Svejnar, J. (2002), "Transition economies: performance and challenges", The Journal of Economic Perspectives, Vol. 16 No. 1, pp. 3-28.

Szlachta, J. (1993), Rozwój regionalny Polski w warunkach transformacji gospodarczej, Fundacja im. Friedricha Eberta w Polsce, Warszawa.

Szlachta, J. (1994), Regionalne prawidłowości procesu transformacji, in: Rozwój regionalny w Polsce, Fundacja im. Friedricha Eberta w Polsce, Warszawa.

Szubert-Zarzeczny, U. (1985), "Polityka turystyczna państwa i jej wpływ na rozwój usług turystycznych w Polsce w latach 1945-1979", PhD thesis, Akademia Ekonomiczna, Wrocław.

Szubert-Zarzeczny, U. (1995), "Uwarunkowania rozwoju turystyki w Polsce w okresie transformacji systemowej”, Problemy Turystyki, Vol. 18 Nos 1/2, pp. 59-69. 
Szubert-Zarzeczny, U. (2001), "Turystyka w rozwoju gospodarczym Polski”, Edukacja, Wydaw, WSZ Edukacja, Wyższa Szkoła Zarządzania we Wrocławiu, Wrocław.

Theuns, H.L. (1993), "Government policies and tourism sector development in Poland and implications for the organization structure of the NTO", Institutional Strengthening, Working Paper No. II, Instytut Turystyki, Warszawa.

van Asselt, M.B.A., van't Klooster, S.A., van Notten, P.W.F. and Smits, L.A. (2012), Foresight in Action: Developing Policy-Oriented Scenarios, Earthscan from Routledge, New York, NY.

Vecchiato, R. and Roveda, C. (2014), "Foresight for public procurement and regional innovation policy: the case of Lombardy", Research Policy, Vol. 43 No. 2, pp. 438-50.

Witt, S.F. and Witt, C.M. (1992), Modeling and Forecasting Demand in Tourism, Academic Press, New York, NY.

Witt, C.A. and Witt, S.F. (1995), "Forecasting tourism demand: a review of empirical research", International Journal of Forecasting, Vol. 11 No. 3, pp. 447-75.

Woo, W.T. (1994), "The art of reforming centrally planned economies: comparing China, Poland, and Russia", Journal of Comparative Economics, Vol. 18 No. 3, pp. 276-308.

Zasady wjazdu obywateli polskich do poszczególnych państw (2015), Ministerstwo Spraw Zagranicznych, available at: www.msz.gov.pl (accessed May 2015).

Zbieć, E. (1994), "Fundusze publiczne zaangażowane w finansowanie bieżących i majątkowych potrzeb turystyki oraz jej otoczenia", Problemy Turystyki, Vol. 17 Nos 3-4, pp. 3-17.

Zorska, A. (1998), Ku globalizacji. Przemiany w korporacjach transnarodowych i gospodarce światowej, PWN, Warszawa.

\section{Further reading}

Gryszel, P. (2007), "Zarys historii turystyki w Polsce”, available at: www.lotur.eu/UploadFiles/524/178/ 1265187566-Historia_turystyki_W_Polsce_DOT_IT.pdf (accessed May 10, 2015).

\section{Corresponding author}

Matylda Awedyk can be contacted at: awedyk@awf.poznan.pl

For instructions on how to order reprints of this article, please visit our website: 